\title{
Designing Service Business Models for the Internet of Things: Aspects from Manufacturing Firms
}

\author{
Chia Tai Angus Lai ${ }^{1,2,}$, Paul R Jackson ${ }^{1}$, Wei Jiang ${ }^{2}$ \\ ${ }^{1}$ Alliance Manchester Business School, University of Manchester, Manchester, UK \\ ${ }^{2}$ Antai College of Economics and Management, Shanghai Jiaotong University, Shanghai, PRC
}

Email address:

lai_ngs@yahoo.com (C. T. A. Lai)

${ }^{*}$ Corresponding author

\section{To cite this article:}

Chia Tai Angus Lai, Paul R Jackson, Wei Jiang. Designing Service Business Models for the Internet of Things: Aspects from Manufacturing Firms. American Journal of Management Science and Engineering. Vol. 3, No. 2, 2018, pp. 7-22. doi: 10.11648/j.ajmse.20180302.11

Received: August 17, 2018; Accepted: September 6, 2018; Published: October 9, 2018

\begin{abstract}
The increasing pervasiveness of the Internet of Things (IoT) has offered a wealth of business model opportunities. Many conventional product-based companies are seeking to increase their competitiveness by moving toward a service-based business model where IoT can bring tremendous opportunities. These traditional product-sales manufacturing firms are required to look at business models beyond their conventional product-focused, firm-centric core competence business model innovation and respond to fast changing digitalization dynamics focused on promoting service-centric solution availability instead of physical products. However, studies and literatures have not yet provided profound and actionable approaches to service business models in IoT-driven environments for manufacturing firms. This research aims to fill the gap and elaborate the guiding principle for designing service business models for the Internet of Things in manufacturing firms. The guiding principles are derived from illustration of value of the Internet of Things and systemic review of academic literatures focusing on IoT business models. Exemplary real-world IoT service business models cases are demonstrating the applicability of the proposed guiding principles. Evaluation of the applicability of guiding principles pertaining to the emerging context of IoT business model can enable researchers and practitioners to visualize and analyze service business model design in a structured and actionable way.
\end{abstract}

Keywords: Business Model, Internet of Things, Business Ecosystem, Value Co-creation, Service-Dominant Logic

\section{Introduction}

Many real world Internet of Things (IoT) applications have been postulated in many industries: the domain not only covers conventional industrial sectors, but also the consuming industry of everyday life, where IoT can bring significant improvement, even leading to new business models. However, the business model based on today's largely static or historical information architectures is facing challenges as new ways of creating value arise between firms, clients, and other stakeholders - in other words, an ecosystem business model instead of a firm-centric business model. In durable goods industrial sectors, selling products is no longer simply goods exchange for their monetary valuefor example, paying by usage or by performance is now a common option. In the consumer industry, customer purchasing behavior under a dynamic environment is based on situational preference and analyzing customer behavior is more difficult based on today's general customer survey; for example, firms need to adjust by means of dynamic pricing to attract customer purchasing desirability based on real time data analysis of specific customers and locations, or, in the industrial service industry, providing a real-time remote monitoring service to tailor customers' specific needs becomes more critical and necessary. By providing additional service through precise analysis evolved with the use of a multitude of sensors, firms can help to monitor and manage their clients' purchasing behaviors, operating equipment or manufacturing processes more precisely, raising efficiency and productivity, and hence creating more revenue opportunities. In certain situations, operating environments can be monitored continuously for hazardous environments where objects can take predictive corrective action to avoid 
safety incidents, reduce risks, and avoid costs incurred by operating systems damage or down time. With IoT technology, firms now have the capability, or simply more opportunities, to innovate business models that give them an advantage over their competitors [1].

IoT is a broad concept and a consensus has yet to be built concerning a common definition. This paper focuses on conventional manufacturing companies expanding their new offering in providing IoT services to bring value to their clients and other stakeholders, hence generate additional revenue and profitability. In the IoT service domain, information is gathered from various sensors through networks, processed for information analytics and optimization in a central repository and finally suited to decision making. These services are expected to find users in a wide range of smart applications related to home, factories, energy, healthcare, logistics and maintenance and could revolutionize society. Especially, there are several initiatives aimed at promoting IoT services in the industry sector, including "Industry 4.0" in Germany, "Made in China 2025" in China, the "Industrial Internet" in the United States (US) and the "Industrial Value Chain Initiative" in Japan (2). In particular industry 4.0 foster automation and data exchange over cyber-physical systems, internet of things, cloud computing and cognitive computing, which communicate and cooperate each other and with human in real time both internally and across organization service offered and used by actors of the value chain (3). Hermann et al. proposed six design principles for Industry 4.0 implementation; they are interoperability, virtualization, decentralization, real-time capability, service orientation and modularity which rely on full transparency of communication among physical things, physical and virtual network (4). Some examples are machine which can predict failures and trigger maintenance processes autonomously or self-organized logistics which react to unexpected changes in production, as well as services through machine to machine interface. All these effects requiring everything is interlinked with everything else, it is a fair assumption of driving force behind IoT (5).

There are many literatures articulating that IoT will enable traditional manufacturing firms to innovate new business models; these studies will be examined thoroughly in later sections. These literatures indicate that technology advancement in terms of product or service innovation alone may not sustain business life unless a viable and sustainable business model exists. A viable business model will play an important role when it comes to leveraging the opportunities if new technology innovates, matures, and is cost effectivebut how will IoT provide us with these many business opportunities? What are the main differences when designing IoT business models compared with conventional firmcentric core competence-based business models? And what are the critical guidelines when developing service business models for IoT, if theoretically they could be in a different spectrum from the traditional business model? In this paper, these questions are addressed and provide input and recommendations from both theoretical and practical perspectives, aiming to analyze the critical guiding principles when designing an IoT business model in manufacturing firms, where it is argued there should be a business model service-centric in nature.

This paper begins with a definition of the Internet of Things, with further elaboration on what are the potential applications and value of IoT, followed by a brief discussion on business models framework mostly applied to IoT business model from a theoretical perspective, as well as the discussion on busienss model development relating to technology advancement, where we believe that these theories or frameworks are a critical link in our studies. Subsequently, a systematic review of literatures is conducted addressing designing business models for IoT for manufacturing firms; from there, this study derives proposed guiding principles for when a company decides to adopt IoT to develop a new business model in service nature. Finally several exemplary real-world practical cases are illustrated on how legitimate manufacturing companies develop their new service-centric business models based on IoT technology, and hence test the guiding principles proposed.

\section{The Value of the Internet of Things}

It is emerging that the physical world itself is becoming a type of information system, called the Internet of Things. Sensors and actuators embedded in physical objects are linked through wired and mostly wireless networks, often using the same Internet Protocol (IP) that connects the internet to a central data server to collect and exchange a huge amount of information for analysis. These objects can be simple, like performance data collectors to sense the environment, up to smart objects that intelligently communicate and perform complex interactive tasks. It is revolutionary that these physical information systems are now beginning to be deployed, and some of them even work largely without human intervention.

IoT technology can enable firms to promote solutions which integrate product and service operations-for instance, wireless sensor networks or remote monitoring systems that consist of disturbed autonomous sensor-equipped devices to monitor the physical or environmental conditions and that can cooperate with internal systems to monitor the real-time status of a product or equipment, such as its location, temperature, movement or even component utilization status [6], cloud computing, and finally IoT applications to enable device-to-device and human-to-device interaction in a reliable and robust manner [7]. The true value of IoT for enterprises can be realized when connected devices are able to integrate with in-house business intelligence applications, traditional enterprise resource planning (ERP) systems, and supply chain systems, collecting big data and business analytics for further decision support systems [8].

The adoption of new technology is rapidly gaining momentum as technological, societal, and competitive pressures push firms to innovate their new offering and business model. Data collection and analytical capability 
from IoT technology is an advantage for company executives, enabling them to consider that the information they collect could do even more than support product and service offerings: companies commercializing big data on their own have the advantages of economies of scale, control over strategy, and much greater revenue potential. Partnerships built upon IoT ecosystems also share risks and take advantage of the partners' knowledge and skills, assets, or data to create new opportunities and get to market quickly.

A great deal of advanced technology has been developed in the IoT field for conventional manufacturers. However, in this paper authors do not focus on IoT from a technical perspective: instead, it examines the value of IoT which can enable these firms to redesign or innovate new business models from better generated information and analyses, which can enhance decision-making significantly and so establish a business model for which clients are willing to pay. Before investigates how to a design business model for IoT, firstly has to understand the power of IoT in general. In brief, the fundamental attributes of IoT technology can be summarized as follows: (i) IoT is a global and real-time solution; (ii) IoT is mainly wireless oriented; (iii) IoT has the capability of remote monitoring of the environment and tracking objects; (iv) IoT is able to collect and exchange data from objects; and v) IoT is able to provide comprehensive data analysis about its surrounding environments [9-10]. Based on the key attributes of IoT, technology trends, and a literature review, it is concluded that IoT can enhance manufacturing firms' value in various areas: tracking behaviors and monitoring; enhanced situational awareness; decision-making support; automation; navigation and control; optimized resource consumption; information sharing and collaboration; and complex autonomous systems. Followed by elaborating on how each of these values of IoT can be commercialized and hence develop possible economic power in the market, which will act as a critical component of the firm's business model innovation.

\subsection{Tracking Behaviors and Monitoring}

When 'things' have smart sensors embedded, fundamentally they can track the movement of the object and can even communicate or interact with the object if they are smart enough. However, tracking objects may not itself create value: firms have to analyze the movement of objects in a valuable pattern and hence create business opportunities, either from more productive or an increase in revenue perspective. Real-time information processing technology based on sensors can realize instant monitoring of almost every link in the supply chain, from commodity design to raw material purchasing, production, transportation, storage, and distribution and after sales service [6]. For example, traditional manufacturers installing RFID (Radio-frequency identification) tags in products can improve inventory management; jet engine providers can track flying hours for both a chargeable usage business model and predictive maintenance; consumers wearing sensor devices can keep track of exercise outcomes as well as health monitoring; insurance companies can use sensors installed in cars to analyze driver behaviors to determine premium charges; and, in retailing, smart chips installed in a membership card can track and therefore predict purchasing power.

\subsection{Enhanced Situational Awareness}

Data collected from numerous sensors can be analyzed for situational awareness, wired or wirelessly. These data patterns can range from a simple dataset to voice or high resolution visualization tools; they can give decision makers a heightened awareness of real-time environmental conditions. Good situational awareness is an important factor for minimizing property damage and injury, and for saving people's lives in emergency response operations [9]. Some examples are real-time video cameras for monitoring purposes and infra-red detectors for security functions, up to more complex traffic control and people flow management.

\subsection{Decision-Making Support}

IoT can also support more complex human planning and decision making. This requires building sophisticated statistical models in order to generate certain patterns or graphical displays from big data analytics. For example, shop floor production line design can be based on analysis of the production flow in order to avoid a production bottleneck; public traffic lights can be designed based on analysis of big data from transportation situation patterns. In healthcare, sensor links offer the possibility of monitoring a patient's symptoms in real time, hence allowing physicians to better diagnose disease and prescribe tailored treatment. Or, on a more sophisticated level, hundreds of sensors located in a sensitive earthquake zone can possibly predict activity and provide an early alert.

\subsection{Automation}

Manufacturing firms are utilizing sensors and actuators in their precision machinery to modify processes through an automated looping and feedback process. These intelligent actuators can fine tune the production position or temperature, or modify ingredients based on situational analysis. This continuous looping from data to automated applications can raise productivity, as systems that adjust automatically to complex situations make many human interventions unnecessary; this move will hence help to enhance process optimization.

\subsection{Navigation and Control}

Cars, trains, and buses, along with the roads and the rails, equipped with sensors, actuators, and processing power may provide important information to drivers and passengers to allow better navigation and uphold safety. A few car companies are already testing their autopilot or robot navigation car: soon these cars will be running on the road based on sensors and navigation systems in the cars connecting to the cloud and satellite for driving. These cars respond to real-time traffic movements of the city, and are 
calibrated to reduce congestion at bottlenecks in the city and to service pick-up areas that are most frequently used. In a similar concept, an IoT smart city is based on the concept that the status and performance of each building and urban public facility, such as walkways, cycle paths, subways, rail lines, and bus corridors, is continuously monitored by the city government and made available to third parties via a series of application programming interfaces (API). These APIs can be available for the public to improve their urban life.

\subsection{Optimized Resource Consumption}

Networked sensors and automated feedback mechanisms can change usage patterns for scarce resources, particularly in energy consumption, often by enabling more dynamic pricing [1]. Smart meters can show residential and industrial customers their energy usage and the real-time cost on their handy mobile device and application. Based on time of use pricing, commercial customers can shift energy-intensive processes and production away from high priced periods of peak energy demand to save costs. HVAC (heating, ventilation, and air-conditioning) solution providers can build district cooling facilities to provide an intensive compound by charging according to usage through smart meters everywhere. A central cooling facility can also generate ice storage during non-peak energy consumption periods and can be used for air conditioning and chilled water on a usage chargeable basis, so firms and clients together can maintain sustainable energy consumption.

\subsection{Information Sharing and Collaboration}

IoT can provide identification and authentication through fingerprint or face recognition systems for access control. Sensor devices enable functions centered on patients, and in particular on diagnosing patient conditions, providing realtime information on patient health indicators. Searches can be easily conducted for things that help in finding objects that have been forgotten, lost, or even stolen. Information sharing and collaboration in IoT can occur between people, between people and things, and between things. Sensing a predefined event is usually critical for information sharing and collaboration; it enhances situational awareness and avoids information delay and distortion [7].

\subsection{Complex Autonomous Systems}

The most demanding use of the Internet of Things involves the rapid, real-time sensing of unpredictable conditions and an instantaneous response guided by the automated system without human intervention [1]. Other than autopilot cars in the progress of development, scientists have also developed robots that maintain facilities or clean up toxic waste. In the defense sector, unmanned aircraft and armed forces are being developed and used in real combat. While such autonomous systems will be challenging to develop and perfect, they promise major gains in safety, productivity, and cost.

\section{Business Model}

This section outlines the grounded theory and framework developed for business models over the past few decades. This study particularly identify the most frequently applied theories in IoT business model-related literatures which will address in more detail manner at following sections. These theoretical frameworks should be inspiring and provide a level of abstraction that will help when scholars choose to illustrate business model development for the Internet of Things from different angles, while the literatures will form the basis for discussion of whether the frameworks are concrete enough to be actionable for innovators in business and society at large.

Consensus on a common definition of the business model has yet to be reached in the management literatures [11]. However, one early definition that has been widely influential stems from Amit and Zott [12]: "A business model depicts the content, structure, and governance of transactions designed so as to create value through the exploitation of business opportunities". Also, a business model is an organization's approach to generating revenue at a reasonable cost and incorporates assumptions about how it will both create and capture value to benefit enterprises [13]. Essentially, every company has a business model, whether it articulates it or not. However, complications arise with the most basic questions. What is a business model? What constitutes the firm's business model? Chesbrough [14] suggested that a business model performs two important functions: value creation and value capture. Similarly, Teece [15] defined the essence of a business model as defining the manner by which the enterprise delivers value to customers, entices customers to pay for value and converts payment into profit. Pavie et al. [15] offered a good overview of various business model concepts in their 2013 paper for the ESSEC business school; no matter what market a business organization is competing in, it will - either implicitly or explicitly - create or apply a business model. A business model can be defined as the architecture and mechanism of actual value creation by an organization [16]. All these concepts have in common a focus on the rationale for how an organization creates, delivers and captures value.

More detailed frameworks for the design and classification of business models have been developed since the early publications on the topics. Teece [17] defines a business model as reflecting management's hypothesis about what customers want, how they want it and how an enterprise can best meet those needs and be paid. Gassmann, Frankenberger and Csik [18-20] employ a conceptualization that consists of four central dimensions - the who, the what, the how and the value - in the magic triangle. By answering the four associated questions and delineating 1) the target customers, 2) the value proposition for the customers, 3) the value chain behind the creation of this value and 4) the revenue model that captures the value, a business model can then be established. Based on this magic triangle, Gassmann's St. Gallen Business Model Navigator (BMN) identified 55 
repetitive patterns that form the core of many new business models, having looked at several hundred business model innovators. Alexander Osterwalder [21] introduced the business model canvas (BMC) in the Business Model Generation Handbook, offering a set of nine interdependent "building blocks", beginning with key partners and key activities, together with key resources, moving on to the value proposition to target the customer segment based on customer relationships and channels and ending with the cost structure and revenue streams defined by the other elements. This business model canvas aims to expand along with the sum of resources and activities which the company organizes and implements in order to provide a specific value for a particular target segment [22].

These frameworks developed appear to analyse the related challenges of innovating and implementing new business models in practice [23]. In particular, technology can bring about disruptive business model opportunities in terms of the ability to experiment and through progressive introductions of new products or services. Systematic data collection on usage and performance is important in the development of business models [14]. From another angle, challenges have also been witnessed in emerging industries with regard to technology, application and organization. It is argued that there is the need for a new business model or novel technology to connect ecosystem stakeholders and initiate a new way of commercializing the business model and technology [24]. These challenges require stakeholders to achieve interoperability between different levels of the organizations to cope with uncertainties [25], [26]. Therefore, it is argued that while existing business model templates and frameworks are adequate for examining the challenges faced by single existing organizations [21, 27], they are less suited to analysing the interdependent nature of growth and success among companies that are evolving in the same innovation "ecosystem" [24]. Traditional industrial-era business models held that competitive advantage was based on product excellence, in-house technological innovation and careful management of scarce resources and supply chains [29]. More recent academic research suggests the need to expand the focus in business models from a single company point of view to an ecosystem perspective [30], particularly in the climate of increasing complexity, with more adaptive technical solutions and changes in the roles of business actors compared to the traditional way of managing partners to support firm-centric value design. Furthermore, companies are seeking new commercialized offerings, shifting the focus from industry-specific applications to applications spanning multiple industries; under such circumstances, the challenges increase substantially [25]. Zott and Amit [31] defined a business model as a system of activities dependent on each other through the focal company and the surrounding network. Adopting the established technologies of one industry to develop innovative products and services in another industry is ultimately the cornerstone of a breakthrough in a new offering in today's business society, although challenges need to be overcome. In building business models for emerging ecosystems, the most critical challenges typically are not at the firm level, but lie at the ecosystem or network level and industry interfaces [32]. Changes in industry boundaries and service architectures require the development of value design from an ecosystem business model perspective. Companies are sometimes forced to work on development within a network of partners, which include their customers or even competitors. This implies not only a lead users' approach but also encompasses an entire ecosystem as a facilitator. In the digital world, the one who brings the most developers to its platform wins [33].

\section{Business Models for the Internet of Things: Literature Review}

As discussed in the earlier business model section, a firm cannot create and capture value out of an innovative idea or technological development alone: that by itself does not represent any value until it is commercialized in some way via a business model. Even firms owning leading edge technology cannot sustain competitive advantage without a viable business model. However, we cannot rule out that advances in technology have a significant impact on the business model that a company operates [34]. Rapid technology advance in a way forces a firm to adjust quickly and to modify business models in order to adopt a market challenge. The characteristics and increasing power of IoT's pervasiveness and ubiquity undoubtedly drive the development of a new business model [35]. In terms of commercializing an IoT business, it differs from the traditional firm-centric core competence type of business model innovation. Firms need to collaborate with partners and other companies across industries because of the nature of the IoT ecosystem [36].

In this section, we have investigated a range of twenty-one literatures focusing on business models for IoT (complete list illustrate in Table 2. Among these literatures, there are fifteen literatures related to our product/service/manufacture contextual research scope, if we rule out two literatures specific to healthcare, two focused on logistics, one exclusively for smart cities and one for telecom service. These 15 literatures in general are grouped into: 1) research on technology and different IoT technology layers, and what business values bring to business model development which enables additional value that gives rise to more business model innovation opportunities; 2) scholarly attempts seeking to increase understanding of the emerging IoT business model in terms of matching the framework introduced in the previous section; the most prevalent are the business model canvas (BMC) and Gassmann's St. Gallen Business Model Navigator (BMN), where 55 business model patterns were categorized; and 3) research applying various models and approaches that are normally used in the information technology and system design areas: researchers believe that these models can be adopted in IoT to replace the conventional business model innovation framework. 
Bucherer and Uckelmann [37] emphasized that the business model for IoT has to derive from value creation in IoT, particularly the elaboration value of information (law of information); service focus instead of product focus opportunities; the principle of revenue generation in the IoT business model; and utilizing Osterwalder's business model canvas (BMC) to illustrate exemplary business model scenarios for the Internet of Things. Chan [36] proposes a framework based on Osterwalder's magic triangle of BMN focusing on who, where, and why, with the intention of addressing how, and then integrating with IoT strategy, tactics, and value chain elements. Dijkman et al. [38] present a business model framework for IoT application through a literature survey, thus matching real case IoT applications with the business model canvas. A comprehensive study of business models and the Internet of Things has been written by Fleisch, Weinberger and Wortmann [33]. A Bosch IoT lab white paper, it investigates the economic power of IoT from both business and technology perspectives, followed by a business model pattern matching Gassmann's 55 identified business model patterns. Two critical criteria, value creation and high resolution management, identified as valuable in IoT, are used in a business model pattern suitable for IoT [33]. IoT enables business processes with different properties when compared with common enterprise service modeling, provides IoT-aware process challenges, and contributes to firms' desire to redesign processes based on IoT technology [39]. Ide et al. [40] applied a lean design methodology to business models and applied it to IoT business model development. The authors repeatedly used design business model hypotheses in their research, by means of which corporate businesses can create new business value utilizing IoT, mainly focused on the value of revenue generation in a lean design. A generic business model framework for IoT through literature analysis and interviews follows a test framework in real-world case studies under the business model canvas (BMC). The findings suggest that capability for data analytics is an essential element of IoT service [35]. Keskin and Kennedy [41] believe that in order to achieve the highest profit, firms should redesign their service business models around externalities across markets that link through platforms and be specific about which markets to serve. Their research focuses on a number of business service models that link four sides of a market, and compare the advantages and disadvantages of network externalities generated by IoT in each model. Similarly, Keskin, Tanrisever and Demirkan [42] examine the opportunities and challenges of different business models in IoT-enabled markets and provide a basic roadmap to managers for sustainable growth. In the long run, manufacturers may need to move to a fully integrated business model. Kralewski [22] applied Gassmann's 55 business model patterns and concluded that 33 models can be applied to the Internet of Things based on the magic triangle definition. Lai, Jackson and Jiang [10] illustrate that manufacturing firms establish an advanced service business model by utilizing advanced IoT technology, helping firms shift to service-dominant business: a single in-depth case study was examined. Leminen et al. [30] suggest a four box framework for IoT business model analysis which is adapted from Osterwalder's business model canvas. They consider business model canvas thinking useful for the endeavor due to it suggested value proposition, customer, infrastructure, and financial perspective as the basic elements of business models. They consider the complexity of the IoT ecosystem and closeness to customers as the two foundational dimensions in the framework to analyze the diverse aspects of IoT in a 2 X2 matrix framework for business model design [30]. $\mathrm{Li}$ and $\mathrm{Xu}$ [43] define the IoT business model as a multidimensional structure composed of technology, industry, policy, and strategy, four dimensions based on the multiple open platform model to design an IoT business model. Turber et al.'s [44] research is the first to propose that service-dominant logic provides the right perspective when applied to a business model design in the IoT environment. Fundamentally different from the traditional business model in the IoT environment are value co-creation collaboration within the ecosystem, service-centered or solution revenue generation instead of product selling, operant resource integration, and capitalized value of shared information [44]. Westerlund, Leminen and Rajahonka [45] investigate challenges pertaining to business model design in the emerging context of IoT in relation to two underlying trends: 1) the change of focus from viewing IoT primarily as a technology platform to viewing it as a business ecosystem; and 2) the shift from focusing on the business model of a firm to designing an ecosystem business model.

From the descriptive statistics (Table 1), the most applied theory and framework are Osterwalder and Pigneur's business model canvas (BMC), which accounts for 47 percent (7 of 15) of literatures we reviewed, servicedominant (S-D) logic, which accounts for 27 percent (4 of 15 ), and St. Gallen Business Model Navigators (BMN), with 55 business model patterns accounting for 27 percent (4 of 15 ), they are not mutually exclusive. From the business patterns discussed in these literatures, the majority of papers mention that IoT can enable a product-focused company to move toward innovating a service-centric or service-enabled business model, with IoT technology value co-creation becoming critical when designing an IoT business model due to a firm being unable to work alone and design a business model based on its own core competence and firm-centric nature under the complex IoT environment. Instead, working with stakeholders to co-create commercial value is essential and critical to the development of a win-win ecosystem business model, the end purpose being to maintain a longerterm relationship with clients or stakeholders. Many literatures also emphasize the criticality of resource integration under the IoT business model, these resources being both intangible (core competence, creativity, information, partnership spirit, knowledge, and skills) and tangible (hardware, software, applications) from different actors, and equally important under the complex ecosystem environment. Please refer to Table 2 for more detail abstraction of each study. 
Table 1. Descriptive statistics of literature review.

\begin{tabular}{lll}
\hline Descriptive statistics - Literature Review & number of studies & \% \\
\hline Theory Applied & 7 & $47 \%$ \\
Business Model Canvas (BMC) & 4 & $27 \%$ \\
Business Model Navigator (BMN) & 4 & $27 \%$ \\
Service-dominant logic & 10 & $67 \%$ \\
Business Patterns & 8 & $53 \%$ \\
Service-centric business model & 9 & $60 \%$ \\
Value co-creation & 7 & $47 \%$ \\
Ecosystem business model design & 8 & $53 \%$ \\
Value of Information and Data & 7 & $47 \%$ \\
Resource integration (tangible and intangible) & & $7 \%$ \\
Maintain long term relationship perspective & & \\
\hline
\end{tabular}

Table 2. Summary of IoT business models literature review.

\begin{tabular}{|c|c|c|c|c|}
\hline AUTHORS & TITLE & PATTERNS & SEGMENTS & THEORY \\
\hline $\begin{array}{l}\text { Bucherer \& } \\
\text { Uckelmann, } 2011 \text { [37] }\end{array}$ & $\begin{array}{l}\text { Business models for the Internet of } \\
\text { Things }\end{array}$ & $\begin{array}{l}\text { Service as new type of business in IoT (service-centric), } \\
\text { value-focused perspective from end users' involvement } \\
\text { (value co-creation), information as major source of value } \\
\text { creation, IoT value partnership (ecosystem), integration of } \\
\text { different actors (resource integration), }\end{array}$ & $\begin{array}{l}\text { Physical } \\
\text { products \& } \\
\text { services }\end{array}$ & $\mathrm{BMC}$ \\
\hline Chan, 2015 [36] & Internet of Things business models & $\begin{array}{l}\text { Service-dominant logic, value co-creation, value network } \\
\text { and ecosystem, maintain long term relationship business } \\
\text { model, information driven value chain }\end{array}$ & $\begin{array}{l}\text { Products \& } \\
\text { services }\end{array}$ & $\begin{array}{l}\text { BMN and } \\
\text { S-D Logic }\end{array}$ \\
\hline $\begin{array}{l}\text { Dijkman et al., } 2015 \\
\text { [38] }\end{array}$ & $\begin{array}{l}\text { Business models for the Internet of } \\
\text { Things }\end{array}$ & $\begin{array}{l}\text { Survey reveal most important building blocks in business } \\
\text { models are value proposition, customer relationship and } \\
\text { key partners (ecosystem) }\end{array}$ & $\begin{array}{l}\text { Manufacturing } \\
\& \text { supply chain }\end{array}$ & $\mathrm{BMC}$ \\
\hline Fan \& Zhou, 2011 & $\begin{array}{l}\text { Analysis of the business model } \\
\text { innovation of the technology of } \\
\text { internet of things in postal } \\
\text { logistics }\end{array}$ & $\begin{array}{l}\text { Value of real-time information, resource integration from } \\
\text { all actors }\end{array}$ & $\begin{array}{l}\text { Supply chain - } \\
\text { logistics }\end{array}$ & \\
\hline $\begin{array}{l}\text { Fleisch, Weinberger \& } \\
\text { Wortmann, } 2015 \text { [33] }\end{array}$ & $\begin{array}{l}\text { Business models and the Internet } \\
\text { of Things }\end{array}$ & $\begin{array}{l}\text { Integration of users and customers (value co-creation), } \\
\text { service orientation, value of data, long term business } \\
\text { relationship (digital add-on, digital lock in, remote usage } \\
\text { and condition monitoring...), challenges on IoT } \\
\text { partnership (IoT ecosystem) }\end{array}$ & $\begin{array}{l}\text { Both digital and } \\
\text { non-digital } \\
\text { industries }\end{array}$ & $\begin{array}{l}\text { BMN, } \\
\text { BMC and } \\
\text { S-D Logic }\end{array}$ \\
\hline $\begin{array}{l}\text { Glova, Sabol \& Vajda, } \\
2014\end{array}$ & $\begin{array}{l}\text { Business models for the internet of } \\
\text { things environment }\end{array}$ & $\begin{array}{l}\text { Integration of products and services, capitalized value of } \\
\text { information, IoT collaborative environment (ecosystem) } \\
\text { with value co--creation with customers and stakeholders }\end{array}$ & Health care & $\mathrm{BMC}$ \\
\hline $\begin{array}{l}\text { Haller \& Magerkurth, } \\
2011[39]\end{array}$ & $\begin{array}{l}\text { The real-time enterprise: IoT- } \\
\text { enabled business processes }\end{array}$ & $\begin{array}{l}\text { Service-oriented architectures and processes under IoT, } \\
\text { data as critical elements of value (real-time) }\end{array}$ & $\begin{array}{l}\text { General } \\
\text { industry }\end{array}$ & \\
\hline Ide et al., 2015 [40] & $\begin{array}{l}\text { A lean design methodology for } \\
\text { business models and its } \\
\text { application to IoT business model } \\
\text { development }\end{array}$ & $\begin{array}{l}\text { Applied to service business of traditional manufacturing } \\
\text { (service-centric), value creation from technology and } \\
\text { create value for customers (value co-creation), IT value } \\
\text { matrix with partnership (IoT ecosystem) }\end{array}$ & Manufacturing & $\mathrm{BMC}$ \\
\hline $\begin{array}{l}\text { Ju, Kim \& Ahn, } 2016 \\
\text { [35] }\end{array}$ & $\begin{array}{l}\text { Prototyping business Models for } \\
\text { IoT service }\end{array}$ & $\begin{array}{l}\text { IoT service business model, IoT ecosystem, actors resource } \\
\text { integration }\end{array}$ & Service & $\mathrm{BMC}$ \\
\hline $\begin{array}{l}\text { Keskin \& Kennedy, } \\
2015[41]\end{array}$ & $\begin{array}{l}\text { Strategies in smart service systems } \\
\text { enabled multi-sided markets: } \\
\text { business models for the Internet of } \\
\text { Things }\end{array}$ & $\begin{array}{l}\text { IoT reinforces the integration of products and service } \\
\text { business model, value creation to all sides of market } \\
\text { instead of consumers only, maintain long term } \\
\text { sustainability, data provide a critical role no matter } \\
\text { chargeable or free of service. }\end{array}$ & Manufacturing & \\
\hline $\begin{array}{l}\text { Keskin, Tanrisever \& } \\
\text { Demirkan, } 2016\end{array}$ & $\begin{array}{l}\text { Sustainable business models for } \\
\text { the Internet of Things }\end{array}$ & $\begin{array}{l}\text { IoT enhances service for durable goods sales, resource } \\
\text { integration between software provider and manufacturers, } \\
\text { maintain long term relationship with customers for durable } \\
\text { goods manufacturers }\end{array}$ & Manufacturing & \\
\hline Kralewski. 2016 [22] & $\begin{array}{l}\text { Business models of Internet of } \\
\text { Things }\end{array}$ & $\begin{array}{l}\text { Each agent has its own business model (IoT ecosystem) } \\
\text { and resource integration (focus on skill and knowledge) }\end{array}$ & $\begin{array}{l}\text { General } \\
\text { industry }\end{array}$ & BMN \\
\hline $\begin{array}{l}\text { Lai, Jackson \& Jiang, } \\
2016[10]\end{array}$ & $\begin{array}{l}\text { Shifting paradigm to service- } \\
\text { dominant logic via Internet-of- } \\
\text { Things with applications in the } \\
\text { elevators industry }\end{array}$ & $\begin{array}{l}\text { Transition to service-dominant logic, maintain long term } \\
\text { relationship with customers, value co-creation, resource } \\
\text { integration and working with partnership (ecosystem), data } \\
\text { as a critical value co-creation with partners }\end{array}$ & Manufacturing & S-D logic \\
\hline $\begin{array}{l}\text { Leminen et al., } 2012 \\
\text { [30] }\end{array}$ & $\begin{array}{l}\text { Towards IoT ecosystems and } \\
\text { business models }\end{array}$ & $\begin{array}{l}\text { IoT ecosystem is the core of business model creation, } \\
\text { value co-creation with actors, resource integration inside } \\
\text { and outside of firms, product and service integrate with } \\
\text { information, principle in service context (service-centric) }\end{array}$ & Manufacturing & $\mathrm{BMC}$ \\
\hline
\end{tabular}




\begin{tabular}{|c|c|c|c|c|}
\hline AUTHORS & TITLE & PATTERNS & SEGMENTS & THEORY \\
\hline Li \& Xu, 2013 [43] & $\begin{array}{l}\text { Research on business model of } \\
\text { Internet of Things base on MOP }\end{array}$ & $\begin{array}{l}\text { Resource integration from multiple platforms (technology, } \\
\text { industry, policy and strategy) }\end{array}$ & $\begin{array}{l}\text { General } \\
\text { industry }\end{array}$ & \\
\hline Liu \& Jia, 2010 & $\begin{array}{l}\text { Business model for drug supply } \\
\text { chain based on the internet of } \\
\text { things }\end{array}$ & Value creation and resource integration among actors & Health care & \\
\hline Perera et al., 2014 & $\begin{array}{l}\text { Sensing as a service model for } \\
\text { smart cities supported by internet } \\
\text { of things }\end{array}$ & $\begin{array}{l}\text { Service-centric IoT business model, resource integration } \\
\text { for service, economic value of data }\end{array}$ & Smart cities & \\
\hline Qin \& Yu, 2012 & $\begin{array}{l}\text { Research on the internet of things } \\
\text { business model of telecom } \\
\text { operators based on the value net }\end{array}$ & $\begin{array}{l}\text { Customer-centric, resource integration, information } \\
\text { sharing and collaboration }\end{array}$ & $\begin{array}{l}\text { Telecom } \\
\text { Service }\end{array}$ & \\
\hline Sun et al., 2012 & $\begin{array}{l}\text { A holistic approach to visualizing } \\
\text { business models for the internet of } \\
\text { things }\end{array}$ & $\begin{array}{l}\text { Resource integration and value chain, IoT partnership } \\
\text { (ecosystem) }\end{array}$ & $\begin{array}{l}\text { Supply chain - } \\
\text { logistics }\end{array}$ & $\mathrm{BMC}$ \\
\hline Turber et al., 2014 [44] & $\begin{array}{l}\text { Designing business models in the } \\
\text { era of Internet of Things }\end{array}$ & $\begin{array}{l}\text { Integration of partners giving rise cross-industry } \\
\text { ecosystems, apply the S-D logic into key artifacts, value } \\
\text { co-creation with customers, value network and partners, } \\
\text { resource integration and multi-partner collaborations }\end{array}$ & $\begin{array}{l}\text { Non-digital } \\
\text { products }\end{array}$ & $\begin{array}{l}\text { BMN and } \\
\text { S-D Logic }\end{array}$ \\
\hline $\begin{array}{l}\text { Westerlund, Leminen \& } \\
\text { Rajahonka, } 2014 \text { [45] }\end{array}$ & $\begin{array}{l}\text { Designing business models for the } \\
\text { Internet of Things }\end{array}$ & $\begin{array}{l}\text { Ecosystem business model, resource integration, monetize } \\
\text { value of information, long term relationship building }\end{array}$ & $\begin{array}{l}\text { General } \\
\text { industry }\end{array}$ & $\mathrm{BMC}$ \\
\hline
\end{tabular}

\section{Guiding Principles for Designing IoT Business Models Aspects from Manufacturing Firms}

This paper does not intend to provide a framework or model design for IoT business models; instead, instead is to propose core guiding principles when designing a business model for IoT for manufacturing firms, and hence elaborate what are the major differences compared with designing conventional business models. Following the above intensive and systematic review of literature on IoT business models, the literature commonly reveals a certain business patterns of perception of IoT business model development (see Table 1 and Table2). Together with study of IoT real world applications and an understanding of IoT technology advancement and its potential value, this section is go deeper into each of the business patterns. By adopting these guiding principles from a theoretical point of view, we aim to provide contributions for manufacturing firms when attempting to design innovative business models adopting this emerging technology, inspiring firms to encompass additional thinking compared with the conventional business model framework.

\subsection{IoT Promotes a Service-Centric Business Model}

Many of the information technology (IT) influenced business models, regardless of the technology from which they emerge, follow the trend of service orientation, a solution with a product and service integration business model [33]. IoT interacts with machines or humans, enabling a company to shift the paradigm from a goods-dominant business model to a service-dominant business model which integrates goods and service to offer a value co-creation solution [10]. Regardless of whether it is providing an additional service by integrating resources in order to promote goods selling or adding on value by selling a service-based solution, the key is treating service as the center of the business model innovation. One feature of IoT is the fact that the service portion of the business model outlined is always information rich and digital in nature: digitalization that extends into the product itself must of necessity lead to an additional service orientation [33]. There are exemplary service-centered business model scenarios for the Internet of Things - for instance, a shift from providing products to providing a service, called 'products as a service' (PaaS), and more manufacturers follow this trend to increase competition through low cost manufacturing [37]. Another example is the focus on providing customers with a way to mine their own insights to choose their own adventures, a type of business model called 'data as a service' (DaaS). More specifically, providing useful information as service providers is 'information as a service' (IaaS), which creates new business opportunities for measuring and billing information. Other service-driven businesses from IoT include providing real-time business analysis for decision making - 'answer as a service' (AaaS) — which hinges on a value proposition from supplying large amounts of processed data with the idea that the client's job-to-be-done is to find answers or develop solutions for its customers. As a summary, we suggest that the key feature of the Internet of Things enabling the service portion of the business models is that it is always digital in nature; hence the theory and practice of service orientation must be critically examined and expanded as necessary against the backdrop of the characteristics of a digital service [33].

\subsection{IoT Facilitates a Value Co-creation Business Model}

The essence of a business model is to create and capture value and, traditionally, value has been created within a firm's core competences with minimal interaction with customers during the development or even the delivery process. The Internet of Things makes it possible to incorporate and interact with customers in any phase of the value creation process; a common view of co-creation is that value is created by collaboration and facilitated by 
technology, before people and organization. The technology has a direct influence on the way value is determined; thus, when a specific IoT technology is integrated with other resources, value is uniquely and phenomenologically determined, as technologies are repeatedly combined or integrated with other operant resources [52]. IoT contributes to the reconfiguration of resources and services to create a new relational network facilitating customer participation in value creation by virtue of interaction with smart objects and embedded sensors. Such technologies enable access to and adaptation, selection, and integration of resources in a continuous process of value co-creation [10, 53]. The fundamentals of the Internet of Things lie within the idea that the network of things can intelligently think for itself. This part of the value creation process is all about taking advantage of the possibilities and using the Internet of Things as a co-creative partner, in the same manner that co-creative collaborative projects are managed today between people using technology as an enabler [54]. When given the possibility to co-create in harmony with connected things, both in parallel and independently, a wider flexibility in the development process will be reached. Essentially, the concepts of value co-creation and collaboration, along with the emerging Internet of Things, have been highlighted and reinforced as important trends for future business model development [10, 53-55].

\subsection{IoT Strives to Maintain a Long-Term Business Relationship Business Model}

IoT, by linking the device at the customer's premises and the company's centralized cloud or in-house data center, is a way to build a connecting relationship, at least in the machine-to-machine context [56]. Further relationship establishment from machine to machine, machine to human, and human to human is defined by the business model the company would like to deploy. As a huge amount of data accumulates in real time or on an interval basis, this creates an opportunity to build the mutual benefits of sharing valuable information around stakeholders. Thus add-on services and co-creation solutions can be provided and can enhance the handshake lock for customers, making it difficult for them to jump ship, therefore purposely designing a longterm relationship business model regardless of whether on a recurring pay basis or free of service, unless poor service is rendered or information from the IoT is not effectively used [10]. Literatures reveal that monetizing an IoT business model is to design a business model from customers' eyes, meaning the establishment of value co-creation around the technology with clients or stakeholders. This co-creation value concept of business establishment will enhance the value of the co-existing relationship and that between firms and customers, hence maintaining the long-term business model based on solutions or analytic information tailor-made to meet specific customer requirements. Thus it is claimed that one of the fundamental benefits of IoT and the key difference compared with conventional business model innovation is building a long-term business relationship model instead of just focusing on a one-time value exchange.

\subsection{IoT Business Models Should Capitalize on the Value of Information}

Traditionally, data are recognized as an asset for internal usage. Companies today consume a growing number of organizational resources and investment for data capturing, storage, processing, and maintenance. However, the value of data conversion to useful information in general is not financially recognized in balance sheets, nor even possibly a revenue generator. As technology advances, data can be collected and analyzed in more efficient and cost effective ways. A company should reconsider its position, asking 'what data can we analyze today?' followed by 'how could we provide useful data to the client in order to promote our products/service?' and 'how might we sell the data?' While designing the IoT-driven new business model, a company should reposition itself from a more innovative angle by looking at ways to monetize big data collected from smart devices, particularly real-time basis data, as a new revenue stream rather than an add-on supplementary service. Thus data with knowledge converting to information by itself may become a major source of value creation and proposition, and so a source of value co-creation between a company and its customers. This includes information only made possible through IoT technologies, as well as existing information on physical products [37]. IoT makes information collection much more efficient on a real-time basis: with sophisticated big data analysis, firms can develop an information base offering a business model, hence integrating the information stream with physical products and the money stream. Moody and Walsh [57] define seven laws of information, explaining the specifics of information compared with other assets. From these 'laws', we can deduce approaches to value cocreation and adopt conceptual value of information in the Internet of Things business model innovation. These 'laws' tell us that: 1) information is shareable and can be shared with others without loss of value; 2) the value of information increases with use and does not provide any value if it is not used at all; 3) information is perishable and depreciates over time; 4) the value of information increases with accuracy; 5) the value of information increases when combined with other information; 6) more information is not necessarily better; and 7) information is not depletable [37, 57]. An innovative and sustainable IoT business model is as pervasive and sought after as it is elusive. We suggest that IoT may or may not directly generate value of information, but definitely acts as an enabling technology, providing better information capabilities to achieve better opportunities through reinvention of the classic business model.

\subsection{IoT Business Model Reinforces Resource Integration}

In designing an IoT business model, a company is not able to operate alone, particularly where evolving, fast-changing, advanced technology is involved. These technologies and the surrounding network facility may not lie in a company's core 
competence and may involve significant investment. To this extent, a company needs to co-create value with not only internal but also external resources, as the prevalent resourcebased view suggests that resources include both tangible and intangible resources [58], and S-D logic further elaborates resources as 'operant' and 'operand' [59]. The primacy of operant resources is established, defined as those that act upon other resources to create benefit, such as knowledge, competence, experience, and so on, over S-D logic's focus on operand resources, which must be acted on to be beneficial, such as natural resources, goods, and money [59-60]. That is, operant resources, such as knowledge and skills, are the underlying source of value to sustain a competitive advantage over others; this fundamentally transforms the traditional thinking that value occurs in exchange for operand resources. It is suggested that the integration of operand and operant resources is fundamental to the co-creation of value under S$\mathrm{D}$ logic [61]. These resources are in a way co-creators when designing an IoT business model: how effectively a company can integrate these resources will decide whether the business model will be operated successfully.

\subsection{IoT Business Model Reflects Business Ecosystem}

As discussed above, regardless of how sophisticated an IoT business model a company would like to deploy, it will evolve more or less different level of partners; therefore, the core of an IoT ecosystem refers to the interconnections of the physical world of things with the virtual world of the internet, the software, hardware, and cloud computing platforms, and the standards commonly used for enabling interconnection [62]. From a business ecosystem perspective, Moore (1993) defines a business ecosystem as "an economic community supported by a foundation of interacting organizations and individuals". A business ecosystem includes the network of buyers, suppliers, and makers of related products or services. Besides the ecosystem's core business consisting of the firms delivering the goods/service along with their customers, market intermediaries, and suppliers, the business ecosystem also includes the owners and other stakeholders of the core, as well as regulatory bodies and competing organizations. Moore [63] argues that the leadership of companies has a strong influence over the co-evolutionary processes: the operation of the system cannot be understood by studying its parts detached from the entity. Thus an IoT ecosystem of co-creating actors is established: essentially, every actor in this IoT ecosystem needs a distinct business model itself to serve its clients, and all co-exist together and share the value that the final customer is willing to pay [64]. Therefore, firms needs to reposition themselves when designing business models for IoT due to the fact that an ecosystem business model is a business model composed of value pillars anchored in ecosystems and focuses on both the firm's method of creating and capturing value and any part of the ecosystem's method of creating and capturing value $[30,45]$. We argue that a viable business model for IoT should change its focus to an ecosystem approach to doing business and, if it uses business model design tools that consider the ecosystem nature of the IoT rather than emphasize an individual company's self-centered objectives, it will move toward a common ecosystem goal instead of different goals for each of the stakeholders in the ecosystem.

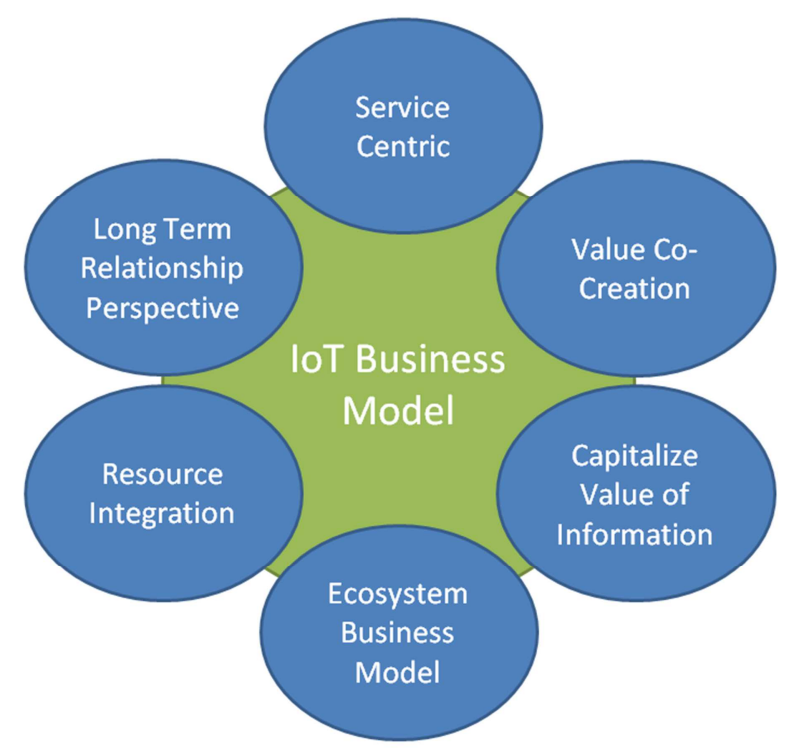

Figure 1. Guiding principles for designing business models for the Internet of Things.

In summary, we offer these guiding principles from a theoretical perspective along with managerial implications for practitioners to truly reflect the need for a business to design a viable business model under the IoT environment. We believe that with these guiding principles, it is possible for a product focus manufacturing firm to develop a service business model from both a conventional core competences and an advanced technology perspective, as summarized as Figure 1.

\section{Exemplary IoT Service Business Model in Manufacturing Firms}

Hereby three IoT business model real-world exemplary cases are introduced in order to construct an interpretation of the proposed guiding principles. The cases selected are all manufacturing companies that traditionally focus on designing and selling innovative products, further developing their service business originally to provide after-sales for the purpose of promoting goods. The last few decades have seen a transition from product focus back up with after-sales service, gradually moving toward a solution business model with an integrated product/service offerings, onto a more service-centric business model where physical products are seen merely as means of distribution of service. Now, these companies are proactively adopting IoT technology in their solution business and hope to provide a more attractive business model to their clients. These practical cases aim to examine the guiding principles this study proposed above with the business model currently deployed in the real-world applications. 
The data collected for this research were obtained from a number of sources. Firstly, information was collected mainly from companies' publicly available documentation and web site information. Secondly, semi-structured interviews were conducted with company leaders, interviews varying in length but typically lasting for one to two hours. The objective was to gain insights into this contemporary phenomenon to understand what criteria a company considers when designing IoT business models. Thirdly, we interviewed various IoT vendors from a digitalization consultant company that helps firms to integrate IoT resources, sensors hardware manufacturers, and a software company that is contracted to develop a user interface application to facilitate more friendly and effective shared information.

Industrial Scientific (www.indsci.com) is a global leading precision gas detector hardware manufacturer mainly operating in the mining, oil refinery, environmental, and hazardous industry. In recent years, the company has shifted its business model gradually from selling products to providing a solution of service. In its vision, it claims that providing great products and services is not enough, but it aims to provide customers with data that give them control over all risks in their operations. The data, known as leading indicators, help them to see problems before they happen and give customers the opportunity to make changes and save lives. The company has pioneered this concept in gas detectors with iNet. Its sister company, Predictive Solutions, is doing the same with safety observations and inspections. When customers have data that include safety equipment and human behavior, they are better equipped to eliminate death in their workplaces.

The newly promoted iNet service adopting IoT technology covers: 1) instrument maintenance: schedules instrument bump tests and calibrates automatically; it will also detect a malfunctioning instrument and send replacement units from the company; 2) information: provides required records on demand; eliminates the prone-to-error task of manually maintaining records; 3) field visibility: understands the instrument being used and uses information to proactively correct poor use behaviors. The idea of the iNet offering was originally co-created with their long term clients by understanding the challenges from their clients, these challenges firstly including difficult justifying what kind of detectors they really required at first; secondly, even purchasing the right equipment and learning to use it in proper way became challenging due to clients being in their own mining or refinery business; thirdly, the highly sophisticated and precision equipment needed to be regularly maintained and calibrated in order to ensure the level of precision: maintaining the equipment at widespread locations was physically impossible, and how was the equipment to function properly and when it needed to be maintained? Finally, collecting and analyzing data needed special knowledge and skill; should the client invest both tangible (investment, assets and employee) and intangible (knowledge and skill) internal resources?
The offering of iNet uses the regular annual total solution fee to cover the entire service which replaces the traditional buying of pieces of equipment plus additional post-sales maintenance fees. The service includes providing the right magnitude of equipment, maintenance (remotely or on-site), data collection, and analysis. The fee structure is based on real requirements on an actual basis; key factors are the customer-centric and service mind-set, the success of which is based on how the company can help the customer to do their job better. This new business model enables efficient and effective use of instruments without redundancy. From the customer side, it is a cost-effective solution that has removed the hassle of managing a gas detection fleet and has made employees safer; they can focus on their own core business. From the company perspective, it will use the instruments more effectively, locking in a long-term win-win relationship with customers and operating a value co-creation chain as well as more integrated resources to better serve customers.

In this case, we recognize the paradigm shift from goods selling to service-oriented; the equipment itself is part of the service provision. A hardware manufacturer even promotes to the customer "do not buy gas detection instruments: we will take care of your instrument and let you focus on your core business."

Ingersoll Rand Trane Air Conditioning (www.trane.com) is one of the world leaders in air conditioning systems, services, and solutions. Trane's mission is to control the comfort of the air for people in their homes and in many of the world's largest and most famous commercial, industrial, and institutional buildings. The company offers a broad range of energy-efficient heating, ventilation, and air conditioning (HVAC) systems, dehumidifying and air cleaning products, service and parts support, advanced building controls, and financing solutions, applying its expertise in environmental technology and energy conservation to make a difference in energy efficiency around the globe.

Trane promotes energy solutions to retrofit and upgrade antiquated HVAC and pneumatic controls for inefficient building and industrial air conditioning systems, these aged systems resulting in high energy usage and comfort issues throughout the building. Trane provides special customized solutions for clients seeking to reduce energy and operational costs and to take advantage of rebates from local utility companies, as well as to better align with an energy sustainability program. This service-oriented solution includes complete assessment of energy efficiency, using Trane Energy Optics to analyze the inefficient root causes, validating and prioritizing energy conservation measures (ECMs). Energy Optics provides a low cost, rapid method of analyzing building performance using smart sensors, meters, and real-time weather data to focus on energy use patterns and behaviors that encompass equipment, controls, energy management, lighting, and services.

This energy conservation focus program enables clients to generate significant energy saving to cover the upgrade investment. Trane can even provide a performance guarantee 
to make sure billing is based on the performance of energy saving by period. By installing sensors and actuators all over the system, integrated with Trane's unique building automation system (BAS), it ensures that all equipment is optimized for maximum savings. Building operators can access their BAS from any device on the web or any mobile device, monitoring equipment, making set point changes, and managing alarms. Trane's wireless communicator eliminates the need for communication wires between the system controller, unit controllers, and zone sensors, making installation easier. The wireless solution is self-repairing; redundant mesh technology maintains communication, rerouting signals around obstructions. These analyzed dashboards provide key information to review key data points, facilitate analysis, and help clients develop energy strategies to control costs to achieve targeted energy saving.

Trane's energy solution business model is based on highly sophisticated resource integration from hardware, software, application, special knowledge, and skills, together with advanced IoT technology-in other words, an ecosystem around HVAC with all stakeholders. From clients' perspective, expected saving from energy consumption can well justify the investment; though a value co-created longterm contract is expected, due to pay back, investment may not be recovered within a short period of time. By building a long-term relationship business model, other business opportunities can also be established, including (but not limited to) repair, spare parts, and other services.

KONE Elevators (www.kone.com), headquartered in Helsinki, Finland, is one of world's leading companies providing solutions for the installation, maintenance, and modernization of elevators and escalators and the maintenance of automatic building doors. KONE is one of the top firms globally in the manufacture of evaluators and escalators, and one of the world's most innovative companies. The company's service philosophy is reflected in its trademark 'people flow', which refers to its market offering that moves people within and between buildings with the help of elevators, escalators, moving sidewalks, and automated doors. One of the company's competencies is to optimize the flow of people through sensors and simulation techniques to provide people flow information to the client and hence provide an innovative service, optimizing the flow of people through and between buildings, instead of just selling equipment [65].

KONE adopts the latest digitalization technology to develop its IoT platform service business model, using realtime data and analytics as preventive maintenance gets smarter. It also means improving customer experience through real-time transparency, or it can mean sustainable smart building, making better use of energy and resources. For users, it signifies a better, personalized experience through the whole elevator and escalator journey. The company has announced its intention to establish an independent organization focused on digitalization solutions, innovate solutions focused on people flow analysis. It is attempting to master people flow in a more effective manner, to adopt a 'digital culture' and co-create a new solution offering together with customer and partners. The vision is to innovate a business model that creates a new revenue stream, embracing the latest digitalization technology in selling solutions based on customers' specific requirements: it is a value co-creation model offering everything the customer needs to resolve a people flow issue.

One of the projects as a practical application, the company is undergoing a new service offering with partners that applies the latest technology, the IoT, enabling devices to be installed in lifts linked to the company's remote monitoring center through the mobile network on a real-time basis. The data transmitted from lifts at remote locations will provide instant information to the cloud server. With fast cloud computing technology equipped with sophisticated data modeling, valuable information will be sent immediately to the company's remote monitoring center for the purpose of detecting any malfunction or potential control system or component failure; such an occurrence will trigger follow-up decision-making to resolve the issue either remotely (machine-to-machine context) or through phone calls or dispatching service technicians to the job site. This project will also integrate the existing company field mobility system in which all service technicians already have a smartphone device on hand, providing their daily working schedule and contents, a location positioning service, spare parts ordering, and the most critical online and offline training modules with regular updates, which will enhance their knowledge and skills with technical tips, fact sheets of malfunction root cause, and short learning modules. During the design of a proof of concept, the company applied a value co-creation design process to gather different sources of input from all its stakeholders. These stakeholders participated in the project collaboratively and were not limited simply to value-inexchange (paying the bill in exchange for a service) or valuein-use (who will use the service). They also need to receive relevant shared information on the project in a real-life application for their own network for decision-making and actions, and this value-in-context needs to be co-created from a longer term perspective.

\section{Findings}

This study aims to provide guiding principles wherein a firm will consider these guidelines when it is intending to transition to a more service-oriented business model by adopting the Internet of Things. Though these guidelines are derived from theoretical studies, together with specific characteristics and the expected economic value of the IoT, we believe they provide appropriate prospects to demonstrate a disruptive technology-based business model which may itself provide leading edge or first mover advantage. However, key is how these business models can really commercialize or monetize.

The three exemplary firms selected, which are all traditional manufacturing companies providing both products and services to their clients over decades, tested the 
guidelines we proposed from a theoretical perspective, as summarized in Table 3. We noticed that all these firms recognized the criticality of the trend toward innovating a service-centric business model while producing a focused business model was becoming more commoditized and price competitive. The service itself can be an independent business, or it can operate together with the product to construct a solution business. It is essential to provide the right value proposition to cater for a client's needs, helping the client to better serve its customers, a true value cocreation framework. IoT technology advancement opens up business opportunities for them to redesign their way of doing business with their clients and partners, together creating a co-existing value network and ecosystem. The winning pattern for these firms is how successfully they integrate internal and external resources, investing in both operant resources-essentially creativity, knowledge, information, and skills are the key resources - together with (mostly external) technological partners. Resource integration with substantial investment is not aiming simply to sell a product and service in one shot (value-in-exchange), but purposely aims to maintain a long-term relationship perspective with clients, hopefully creating a handshake and lock-in business model that competitors will find difficult to penetrate. Furthermore, one of IoT's fundamental characteristics is making data collection much more efficient, mostly in a real-time manner: how these companies can utilize these profound data in a key value proposition will decide if clients are willing to pay to use the information to improve their operation or better serve their clients' customers. All these critical elements are again aligned with the guiding principles proposed for designing a servicecentric business model for the Internet of Things.

Table 3. Summary Applicability of Guiding Principles.

\begin{tabular}{llll}
\hline Guiding Principles & Industrial Scientific & Ingersoll Rand Trane & KONE Elevators \\
\hline Service Centric & $\mathrm{X}$ & $\mathrm{X}$ & $\mathrm{X}$ \\
Value Co-Creation & $\mathrm{X}$ & $\mathrm{X}$ & $\mathrm{X}$ \\
Long Term Relationship Perspective & $\mathrm{X}$ & $\mathrm{X}$ & $\mathrm{X}$ \\
Capitalize Value of Information & $\mathrm{X}$ & $\mathrm{X}$ & $\mathrm{X}$ \\
Resource Integration & $\mathrm{X}$ & $\mathrm{X}$ & $\mathrm{X}$ \\
Business and IoT Ecosystems & $\mathrm{X}$ & $\mathrm{X}$ & $\mathrm{X}$ \\
\hline
\end{tabular}

\section{Conclusions}

The IoT technologies connecting the physical world with the world of the internet promise a number of benefits both to potential customers and to the vendors of the solutions. Despite these benefits, the adoption of these technologies is relatively modest at the current stage. The expected rapid adoption of IoT technologies depends on the stability, diversity, and productivity of the business model innovation that is being formed around these technologies. The technological advancement of the Internet of Things itself is currently helping to overcome some of the technical challenges, from standard protocol, robustness, and reliability of the wireless network to maintainability of the engine (cloud computing) for data analytical modelling, security of the entire ecosystem, data integrity and reliability, and providing anywhere and anytime access in a relatively cost effective way. Apart from technical challenges, a number of studies have begun to investigate or intend further to examine how firms can invent a new business model by effectively utilizing this advanced technology and hence create value for the entire business ecosystem.

The goal of this paper is to inspire the understanding of the IoT domain from the business model design perspective. It analyses the role that IoT has played in business models to date, and derives six critical guiding principles for designing service business models for the Internet of Things in manufacturing firms. It hopefully offers a holistic view and may serve as a means to identify new opportunities for business model innovation frameworks and theory. It has investigated related IoT business model literatures and understood their business model angles for IoT regardless of design, technical, or ecosystem lens, and illustrated them with some real-world examples from practical business case studies. These guiding principles promote an IoT servicecentric business model. IoT facilitates a value co-creation business model and strives to maintain a long-term relationship business model. An IoT business model should capitalize on value of information, reinforce resource integration, and reflect the value of the ecosystem and network partners. This paper is striving that these six guiding principles serve as the foundation to commercialize a business from a managerial perspective instead of focusing only on the disruptive technology perspective, helping manufacturing firms to design a viable business model in an IoT-enabled environment.

There are many aspects apart from technology challenges on which this paper does not shed light, particularly the key challenges of each of the guidelines. For example, there is discussion still to be had on goods- and service-dominant logic, value co-creation or value proposition, the challenges of data as a revenue generator and big data business model innovation, and the challenges of managing an IoT ecosystem in terms of going for common direction: as a total ecosystem provides service value versus different goals for each of the actors in the ecosystem, building an ecosystem business model can be compared with a firmcentric business model. Each of these areas needs much deeper discussion. This paper also does not intend to go into industry- or process-specific discussions, though our 
research focuses on traditional manufacturing firms producing goods and provide post sales service in general. Can these guidelines be generalized to all industries without boundaries? Questions remain to be answered and to be more specifically formulated.

\section{Acknowledgements}

This research is supported by the National Natural Science Foundation of China \#71531010 and \#71325003.

\section{References}

[1] Chui, M., Löffler, M. \& Roberts, R. (2010). The Internet of Things. McKinsey Quarterly, 2, pp. 1-9.

[2] Uchihira, N., Ishimatsu H. \& Inoue K. (2016). IoT Service Business Ecosystem Design in a Global, Competitive, and Collaborative Environment. In: Proceedings of 2016 Portland International Conference on Management of Engineering and Technology (PICMET): Technology Management of Social Innovation, pp. 1195-1201.

[3] Wollschlaeger M., Sauter T. \& Jasperneite J. (2017). The Future of Industrial Communication: Automation Networks in the Era of the Internet of Things and Industry 4.0, IEEE Industrial Electronics Magazine, 11(1), pp. 17-27, 1, March 2017

[4] Hermann M., Pentek T. \& Otto, B (2016). Design Principles for industrie 4.0 scenarios, System Sciences (HICSS), 2016 49th Hawaii International Conference on 4 May 2016, IEEE, pp. $3928-3937$

[5] Sarvari P. A., Ustundag A., Cevikcan E., Kaya I. \& Cebi S. (2018). Technology Roadmap for Industry 4.0. In: Industry 4.0: Managing The Digital Transformation. Springer Series in Advanced Manufacturing. Springer, Cham

[6] Atzori, L., Iera, A. \& Morabito, G. (2010). The Internet of Things: a survey. Computer Networks, 54, pp. 2787-2805.

[7] Lee, I. \& Lee, K. (2015), The Internet of Things (IoT): applications, investments, and challenges for enterprises. Business Horizons. 58, pp. 431-440.

[8] Bradley, J., Barbier, J. \& Handler, D. (2013), Embracing the Internet of Everything to capture your share of \$14.4 trillion. White Paper. CISCO.

[9] Yang, L., Yang, S.-H. \& Plotnick, L. (2013). How the Internet of Things technology enhances emergency response operations. Technological Forecasting and Social Change. 80, pp. 1854-1867.

[10] Lai, C. T. A., Jackson, P. R. \& Jiang, W. (2016). Shifting paradigm to service-dominant logic via Internet-of-Things with applications in the elevators industry. Journal of Management Analytics, 4(1), pp. 35-54.

[11] Zott, C. \& Amit, R. (2002). Measuring the performance implications of business model design: evidence from emerging growth public firms. Working paper, INSEAD, Fontainebleau.

[12] Amit, R. \& Zott, C. (2012). Creating value through business model innovation. MIT Sloan Management Review, 53.
[13] Brandenburger, A. M. \& Stuart, H. W. (1996). Value-based business strategy. Journal of Economics and Management Strategy, 5, pp. 5-24.

[14] Chesbrough, H. (2010). Business model innovation: opportunities and barriers. Long Range Planning, 43, pp. 354 363.

[15] Teece, D. J. (2010). Business models, business strategy and innovation. Long Range Planning, 43, pp. 172-194.

[16] Pavie, X., Hsu, E., Rödle, H. J. T. \& Tapia, R. O. (2013). How to Define and Analyze Business Model Innovation in Service. ESSEC Working Paper No. 1323. Available at SSRN: https://ssrn.com/abstract=2370384 http://dx.doi.org/10.2139/ssrn.2370384.

[17] Teece, D.J. (2007). Explicating Dynamic Capabilities: The Nature and Micro-Foundations of (Sustainable) Enterprise Performance. Strategic Management Journal, 28, pp. 13191350 .

[18] Gassmann, O., Frankenberger, K. \& Csik, M. (2013). Geschäftsmodelle entwickeln: 55 innovative Konzepte mit dem St. Galler Business Model Navigator. Hanser Verlag, Munich.

[19] Gassmann, O., Frankenberger, K. \& Csik, M. (2014). The business model navigator: 55 models that will revolutionise your business. UK: Pearson.

[20] Gassmann, O., Frankenberger, K. \& Csik, M. (2014). Revolutionizing the business model. Management of the fuzzy front end of innovation. Switzerland: Springer.

[21] Osterwalder, A. \& Pigneur, Y. (2010). Business model generation: a handbook for visionaries, game changers, and challengers. John Wiley \& Sons, Hoboken, New Jersey.

[22] Kralewski D. (2016). Business Models of Internet of Things. In: Wrycza S. (eds) Information Systems: Development, Research, Applications, Education. SIGSAND/PLAIS 2016. Lecture Notes in Business Information Processing, 264. Cham: Springer.

[23] Visnjic, I. \& Neely, A. D. (2011). From Processes to Promise: How Complex Service Providers Use Business Model Innovation to Deliver Sustainable Growth. Cambridge: Cambridge Service Alliance, University of Cambridge. Available at: https://cambridgeservicealliance.eng.cam.ac.uk/resources/Do wnloads/whitepaperprint.pdf

[24] Rong, K., Hu, G. Y., Lin, Y., Shi, Y. J. \& Guo, L. (2015). Understanding Business Ecosystem Using a 6c Framework in Internet-of-Things Based Sectors. International Journal of Production Economics, 159, pp. 41-55.

[25] Gassmann, O., Zeschky, M., Wolff, T. \& Stahl, M. (2010). Crossing the Industry-Line: Breakthrough Innovating through Cross-Industry Alliances with "Non-Suppliers". Long Range Planning, 5, pp. 639-654.

[26] Rong, K., Shi, Y. \& Yu, J. (2013). Nurturing Business Ecosystem to Deal with Industry Uncertainties. Industrial Management \& Data Systems, 133(3), pp. 385-402.

[27] Sinfield, J. V., Calder, E., McConnell, B. \& Colson, S. (2012). How to Identify New Business Models. MIT Sloan Management Review, 53(2), pp. 84-90. 
[28] Weiller, C. \& Neely, A. (2013). Business Model Design in an Ecosystem Context. University of Cambridge Working Papers. Cambridge: Cambridge Service Alliance, University of Cambridge, pp. 1-21.

[29] Carbone, P. (2009). The Emerging Promise of Business Ecosystems. Technology Innovation Management Resource. Available at: http://timreview.ca/article/227

[30] Leminen S., Westerlund M., Rajahonka M. \& Siuruainen R. (2012). Towards IOT Ecosystems and Business Models. In: Andreev S., Balandin S., Koucheryavy Y. (eds) Internet of Things, Smart Spaces, and Next Generation Networking. Lecture Notes in Computer Science, vol 7469. Springer, Berlin, Heidelberg. DOI https://doi.org/10.1007/978-3-64232686-8_2.

[31] Zott C. \& Amit, R. (2010). Designing Your Future Business Model: An Activity System Perspective. Long Range Planning, 43, pp. 216-226.

[32] Leminen, S., Rajahonka, M., Westerlund, M. \& Siuruainen, R. (2014). Ecosystem Business Models for the Internet of Things. In: XXIV European Association for Research on Service Conference, Helsinki, Finland, 11-13 September, 2014. European Association for Research on Services (RESER).

[33] Fleisch E., Weinberger M. \& Wortmann F. (2015). Business Models and the Internet of Things (Extended Abstract). In: Podnar Žarko I., Pripužić K., Serrano M. (eds) Interoperability and Open-Source Solutions for the Internet of Things. Lecture Notes in Computer Science, vol 9001. Cham: Springer.

[34] Whitmore, A., Agarwal, A. \& Da Xu, L. (2015). The Internet of Things - a survey of topics and trends. Information Systems Frontiers, 17, pp. 261-274.

[35] Ju, J., Kim, M. S. \& Ahn, J. H. (2016). Prototyping Business Models for IoT Service. Procedia Computer Science, 91, pp. 882-890.

[36] Chan, H. C. (2015). Internet of Things Business Models. Journal of Service Science and Management, 8, pp. 552. Available at: http://dx.doi.org/10.4236/jssm.2015.84056

[37] Bucherer, E. \& Uckelmann, D. (2011). Business Models for the Internet of Things. In: Uckelmann, Harrison and Michahelles (eds.), Architecting the Internet of Things. Berlin: Springer, pp. 253-277.

[38] Dijkman, R., Sprenkels, B., Peeters, T. \& Janssen, A. (2015). Business models for the Internet of Things. International Journal of Information Management, 35, pp. 672-678.

[39] Haller, S. \& Magerkurth, C. (2011). The real-time enterprise: IoT-enabled business processes. IETF IAB Workshop on Interconnecting Smart Objects with the Internet, 2011. CiteSeerX.

[40] Ide, M., Amagai, Y., Aoyama, M. \& Kikushima, Y. (2015). A lean design methodology for business models and its application to IoT business model development. Agile Conference (AGILE). IEEE. pp. 107-111.

[41] Keskin, T. \& Kennedy, D. (2015). Strategies in smart service systems enabled multi-sided markets: business models for the Internet of Things. 48th Hawaii International Conference on System Sciences (HICSS). IEEE. pp. 1443-1452.

[42] Keskin, T., Tanrisever, F. \& Demirkan, H. (2016). Sustainable business models for the Internet of Things. ORMS Today, public article, 43 .

[43] Li H. \& Xu Z. (2013). Research on Business Model of Internet of Things Based on MOP. In: Qi E., Shen J., Dou R. (eds) International Asia Conference on Industrial Engineering and Management Innovation (IEMI2012) Proceedings, pp.1131-1138, Berlin, Heidelberg: Springer.

[44] Turber S., vom Brocke J., Gassmann O. \& Fleisch E. (2014) .Designing Business Models in the Era of Internet of Things. In: Tremblay M.C., VanderMeer D., Rothenberger M., Gupta A., Yoon V. (eds) Advancing the Impact of Design Science: Moving from Theory to Practice. DESRIST 2014. Lecture Notes in Computer Science, vol 8463. Springer, Cham

[45] Westerlund, M., Leminen, S. \& Rajahonka, M. (2014). Designing Business Models for the Internet of Things. Technology Innovation Management Review, 4, pp. 5.

[46] Peng, P. F. \& Zhou, G. Z. (2011). Analysis of the business model innovation of the technology of internet of things in postal logistics, 2011 IEEE 18th International Conference on Industrial Engineering and Engineering Management, DOI: 10.1109/ICIEEM.2011.6035215

[47] Glova, J., Sabol, T. \& Vajda, V. (2014). Business Models for the Internet of Things Environment. Procedia Economics and Finance, 15, pp. 1122-1129.

[48] Liu, L. \& Jia, W. (2010). Business model for drug supply chain based on the internet of things, 2010 2nd IEEE International Conference on Network Infrastructure and Digital Content, DOI: 10.1109/ICNIDC.2010.5657943

[49] Perera, C., Zaslavsky, A., Christen, P. \& Georgakopoulos, D. (2013). Sensing as a service model for smart cities supported by Internet of Things, Transaction on Emerging Telecommunications Technologies, 25(1), pp. 81-93.

[50] Qin, Q. \& Yu, Hao (2015). Research on the internet of things business model of telecom operators based on the value net, Management \& Engineering; Brighton East Iss. 21, pp. 8-12. DOI:10.5503/J.ME.2015.21.002

[51] Sun, Y., Yan, H., Lu, C. et al. (2014). Research on the internet of things business model of telecom operators based on the value net, mUX J Mob User Exp (2012) 1: 4. https://doi.org/10.1186/2192-1121-1-4, Springer Berlin Heidelberg

[52] Akaka, M. A. \& Vargo, S. L. (2014). Technology as an operant resource in service (eco) systems. Information Systems and eBusiness Management. 12, pp. 367-384.

[53] Tommasetti, A., Vesci, M. \& Troisi, O. (2015). The Internet of Things and value co-creation in a service-dominant logic perspective. In: Data management in pervasive systems, pp. 318, Switzerland: Springer.

[54] Mejtoft, T. (2011). Internet of Things and Co-Creation of Value. In: F. Xia, Z. Chan, G. Pan, L. T. Yang and J. Ma, eds., 2011 IEEE 4th International Conference on Internet of Things, Cyber, Physical and Social Computing, pp. 672-677. Institute of Electrical and Electronics Engineers.

[55] Bughin, J., Chui, M. \& Manyika, J. (2010). Clouds, big data, and smart assets: ten tech-enabled business trends to watch. McKinsey Quarterly. 56, pp. 75-86. 
[56] Sampson, S. E. (2010). The unified service theory. In: Maglio, K. \& Spohrer (eds.) Handbook of service science, pp.107-132, New York: Springer.

[57] Moody, D. L. \& Walsh, P. (1999). Measuring the value of information: an asset valuation approach. Paper to be presented at the Seventh European Conference on Information Systems (ECIS'99), Copenhagen Business School, Frederiksberg, Denmark, pp. 496-512.

[58] Barney, J. (1991). Firm resources and sustained competitive advantage. Journal of Management, 17, pp. 99-120.

[59] Vargo, S. L. \& Akaka, M. A. (2009). Service-dominant logic as a foundation for service science: clarifications. Service Science, 1, pp. 32-41.

[60] Constantin, J. A. \& Lusch, R. F. (1994). Understanding resource management. Oxford, OH, The Planning Forum.

[61] Ballantyne, D., Williams, J. \& Aitken, R. (2011). Introduction to service-dominant logic: from propositions to practice. Industrial Marketing Management, 40, pp. 179-180.
[62] Mazhelis, O., Luoma, E. \& Warma, H. (2012). Defining an Internet-of-Things Ecosystem. In: S. Andreev, S. Balandin and Y. Koucheryavy, eds., Internet of Things, Smart Spaces, and Next Generation Networking. Lecture Notes in Computer Science, vol. 7469. Berlin, Heidelberg: Springer.

[63] Moore, J. F. (1993). Predators and Prey: A New Ecology of Competition. Harvard Business Review, 71(3), pp. 75-83.

[64] Lai C.T.A., Jackson P.R. \& Jiang W. (2018). Internet of Things Business Models in Ecosystem Context-Cases of Elevator Services. International Journal of Computer and Software Engineering 3(135), pp. 1-10. DOI: https://doi.org/10.15344/2456-4451/2018/135

[65] Greer, C. R., Lusch, R. F. \& Vargo, S. L. (2016). A service perspective: key managerial insights from service-dominant (SD) logic. New York: Organizational Dynamics. 